\title{
HISTORIA I DZIALALNOŚĆ KATEDRY ARCHEOLOGII CHRZEŚCIJAŃSKIEJ NA AKADEMII TEOLOGII KATOLICKIEJ W WARSZAWIE
}

Kiedy po I wojnie światowej powstała wolna Polska, do pierwszych trzech wydziałów odrodzonego Uniwersytetu Warszawskiego dołączył w roku akademickim 1917/18 Wydział Teologiczny. Władze uczelni powołały na tym wydziale, w roku akademickim 1921/22, profesora zwyczajnego ks. dra Pawła Sztygera na profesora kontraktowego archeologii i sztuki kościelnej ${ }^{1}$. Pracował on na Uniwersytecie Warszawskim do 1934 r., a jego uczniami byli między innymi historyk Kościoła ks. Mieczysław Żywczyński, ks. Antoni Kwieciński (wykładowca archeologii na UW od 1935 r.) oraz ks. Antoni Liedtke.

W początkach lat pięćdziesiątych władze PRL postanowiły wyeliminować z uczelni państwowych wydziały teologiczne i nauk kościelnych. Dnia 2 sierpnia 1954 r. zapadła decyzja Rady Ministrów o wyodrębnieniu Wydziałów Teologicznych Uniwersytetu Warszawskiego i Uniwersytetu Jagiellońskiego i utworzeniu na ich podstawie odrębnej uczelni, której kadrę naukową mieli tworzyć dotychczasowi pracownicy obu wydziałów. Nowa uczelnia Akademia Teologii Katolickiej rozpoczęła działalność dydaktyczną 20 listopada 1954 r. na trzech wydziałach: teologicznym, prawa kanonicznego i filozofii chrześcijańskiej.

Na wydziale Teologicznym ATK utworzono w 1954 r. dwie katedry zajmujące się historią sztuki kościelnej: Katedrę Archeologii Chrześcijańskiej, która istniała już na Wydziale Teologii Katolickiej UW oraz Katedrę Historii Sztuki Kościelnej. Do 1965 r. obie katedry należały do kierunku Historii Kościoła. Studenci tego kierunku uczęszczali na niektóre wykłady prowadzone przez te

${ }^{1}$ Por. P. Styger, Stan obecny i przyszłe zadania archeologii chrześcijańskiej, KT 1-2(19231924) 365-381; Piotr i Pawet w Rzymie w świetle najnowszych badań $i$ wykopalisk, PrzKat 63(1925) 73-75; Wizerunki św. Augustyna na podstawie najstarszych portretów i dokumentów, w: Studia augustyńskie, pr. zbiorowa, Warszawa 1931, 13-24; Boże Narodzenie w sztuce starochrześcijańskiej, GłK 6(1932) 570-574; Katakumby rzymskie, Warszawa 1932; Mozaiki Theotokos w Rzymie z czasów Soboru Efeskiego i ich odnowienie przez papieża Piusa XI, GłK 6(1932) 61-65; Rzymskie katakumby, GłK 6(1932) 178-183, 205-212, 261-267, 397-404; Idea nieśmiertelności u starożytnych chrześcijan w świetle wykopalisk i najnowszych badań archeologicznych, PrzKat 71(1933) 759-760, 775-776, 798-799. 
katedry, natomiast studenci, którzy chcieli studiować archeologię chrześcijańską, historię sztuki lub patrologię, realizowali pełny program studiów przewidziany dla kierunku Historii Kościoła. Obie katedry pełniły na wydziale rolę pomocniczą (ancillae theologiae).

Kierownikiem Katedry Archeologii Chrześcijańskiej był nadal ks. prof. Antoni Kwieciński, który pełnił tę funkcję jeszcze na Uniwersytecie Warszawskim (ur. 1892, kapłan od 1918, dr teologii na UW 1927, licencjat Pontificio Istituto di Archeologia Cristiana 1932, habilitowany na UW 1946, profesor zwyczajny 1957), a w 1966 r. przeszedł na emeryturę ${ }^{2}$. Następnie kierownikiem Katedry został ks. Bolesław Przybyszewski (ur. 1908, kapłan od 1933, dr teologii na UJ 1950, habilitowany na ATK 1967), który prowadził wykłady nie tylko ze sztuki starożytnej i wczesnochrześcijańskiej, ale i średniowiecznej ${ }^{3}$.

Kierownikiem Katedry Historii Sztuki Kościelnej został prowadzący wykłady z tego przedmiotu jeszcze na Wydziale Teologicznym UJ, od roku 1946 jako docent, ks. Tadeusz Kruszyński (ur. 1884, kapłan od 1907, dr teologii na UJ 1911, habilitowany tamże 1926, profesor zwyczajny 1956). W 1957 r. ks. Kruszyński odszedł z Wydziału wraz z innymi profesorami b. Wydziału Teologicznego $\mathrm{UJ}^{4}$. W roku akademickim 1968/69 ks. Janusz Pasierb (ur. 1929, kapłan od 1952, doktorat Pontificio Istituto di Archeologia Cristiana 1963, habilitowany na UW 1964, profesor nadzwyczajny 1972), który był asystentem w Katedrze Historii Sztuki Kościelnej od roku akademickiego 1956/57, opracował dla Katedry Historii Sztuki Kościelnej nowy program studiów o charakterze specjalistycznym tworząc odrębną, samodzielną specjalizację ${ }^{5}$.

Archeologia chrześcijańska utworzyła samodzielną specjalizację na Wydziale Teologicznym ATK w roku akademickim 1971/72, kiedy nowym kierownikiem katedry został ks. Ludwik Stefaniak (ur. 1930, kapłan od 1954, dr teologii na UJ 1954, habilitowany na ATK 1970) ${ }^{6}$.

Reaktywowanie Katedry Archeologii Chrześcijańskiej zdecydowanie poparł prof. Kazimierz Michałowski, który czynnie pomagał w jej organizacji popierając m.in. powołanie mgr. Tadeusza Gołgowskiego (ur. 1943, absolwent archeologii śródziemnomorskiej UW 1965, doktorat na UW 1983) na stanowisko st. asystenta. Katedra miała kształcić specjalistów duchownych i świeckich z zakresu sztuki wczesnochrześcijańskiej w związku ze wspaniałymi odkryciami archeologów polskich na Bliskim Wschodzie (Faras, Dongola). Niestety przedwczesna śmierć ks. Ludwika Stefaniaka (9 III 1972) skomplikowała ambitne plany rozwojowe pozbawiając reaktywowaną Katedrę kierownika i jedynego

Por. Kwiecinski Antoni (1892-1969), SPTK VI 291-292.

3 Por. Ks. Antoni Liedtke (1904-1994), SPTK VI 291-292 i VoxP 13-15(1993-1995) t. 24-29, $729-732$

${ }^{4}$ Por. Kruszyński Tadeusz (1884-1959), SPTK VI 222-227.

5 Por. Pasierb Janusz Stanistaw (1929-1993), SPTK VIII 429-440.

${ }^{6}$ Por. Stefaniak Ludwik Walenty (1930-1972), SPTK VII 167-171. 
samodzielnego pracownika naukowego. Do czasu mianowania nowego kierownika kuratelę nad Katedrą objął ks. Janusz Pasierb, kierownik Katedry Sztuki Kościelnej. Aby pomóc w prowadzeniu zajęć dydaktycznych jedynemu pełnoetatowemu pracownikowi katedry mgr. T. Gołgowskiemu, prof. K. Michałowski skierował na ATK dr. Stefana Jakobielskiego (PAN) i dr Barbarę Ruszczyc (MN), którzy od 1974 r. podjęli pracę na półetatach. Cały ciężar wykładów z archeologii chrześcijańskiej sensu stricto spoczywał na barkach prowadzących zajęcia zlecone: mgr. lic. Tytusa Górskiego (Seminarium Metropolitalne w Krakowie) i doc. Tadeusza Dobrzenieckiego (MN w Warszawie), który oprócz wykładów prowadził także seminarium magisterskie. Od roku akademickiego 1973/74 wspomagała ich doc. Barbara Filarska (ur. 1922, doktorat na UW 1961, habilitacja na UW 1969, profesor KUL 1986) ${ }^{7}$.

W tym trudnym okresie w programie zajęć dominowała tematyka związana $z$ indywidualnymi zainteresowaniami prowadzących je wykładowców. Program studiów charakteryzował się dużą ilością zmian i eksperymentów programowych mających na celu stworzenie własnego specjalistycznego ratio studiorum dopasowanego do profilu uczelni. Podczas pierwszego roku studiów studenci poznawali archeologię i historię Wschodu starożytnego, ze szczególnym uwzględnieniem archeologii krajów związanych z dziejami Starego Testamentu (Palestyna, Mezopotamia, Egipt). Na drugim roku studenci poznawali archeologię i historię starożytnej Grecji i Rzymu, co w sumie dawało im solidną bazę pod rozpoczynające się na roku trzecim właściwe studia z zakresu archeologii chrześcijańskiej. Oprócz wykładów specjalistycznych studentów obowiązywały wykłady z dyscyplin praktycznych, jak muzealnictwo, metodologia wykopalisk archeologicznych oraz dwie wakacyjne praktyki wykopaliskowe. Słuchaczy trzech pierwszych lat studiów obowiązywało studium języka greckiego i łacińskiego, a na wyższych latach lektorat jakiegoś języka orientalnego (do wyboru). Wykłady z archeologii uzupełniały wykłady z teologii dogmatycznej, teologii moralnej, teologii biblijnej, historii Kościoła i historii filozofii, które miały poszerzyć wykształcenie przyszłych absolwentów o dyscypliny teologiczne.

Nowy okres w rozwoju Katedry rozpoczyna się z chwilą objęcia kierownictwa Katedry przez ks. Henryka Muszyńskiego w 1981 r. (ur. 1933, kapłan od 1957, doktor teologii na Instytucie Biblijnym w Jerozolimie 1967, habilitacja na ATK 1984). Przeprowadził on podział archeologii chrześcijańskiej na dwie katedry: Katedrę Chrześcijańskiego Wschodu, której kierownictwo objął osobiście i Katedrę Chrześcijańskiego Zachodu, której kuratorem został ks. Franciszek Stopniak. Od roku akademickiego 1983/84 rozpoczęła w Katedrze pracę etatową (pół etatu) docent B. Filarska (KUL).

W roku akademickim 1982/83 opracowano nowy program studiów uwzględniający specyfikę nowo powstałych katedr. Program ten z pewnymi ko-

\footnotetext{
${ }^{7}$ Por. Profesor Barbara Filarska, VoxP 11-12(1991-1992) t. 20-23, 9-19.
} 
niecznymi modyfikacjami obowiązuje do dnia dzisiejszego. Program dwóch pierwszych lat studiów pozostał w zasadzie bez zmian. Od trzeciego roku studenci wybierali specjalizację „wschodnią” lub „zachodnią” zapoznając się poprzez cykl specjalistycznych wykładów ze specyfiką archeologii i sztuki chrześcijańskiego Wschodu i Zachodu. W trakcie pięcioletnich studiów studenci poznawali także dyscypliny praktyczne, jak muzealnictwo, metodologia wykopalisk archeologicznych i nauki pomocnicze historii oraz odbywali intensywny kurs nauki języka łacińskiego i greckiego oraz wybranego języka orientalnego.

W 1987 r. Katedra Archeologii Chrześcijańskiej zostaje przeniesiona z Wydziału Teologicznego na nowy Wydział Kościelnych Nauk Historycznych i Społecznych, a kierownikiem Katedry Archeologii Chrześcijańskiego Zachodu i kuratorem całego kierunku zostaje prof. B. Filarska (KUL), która juz wcześniej prowadziła wykłady dla studentów tej specjalizacji. W związku $\mathrm{z}$ nowym umiejscowieniem Katedry w strukturze uczelni ograniczono program nauczania nauk teologicznych. Dzięki prof. B. Filarskiej w programie studiów archeologii wczesnochrześcijańskiej ATK pojawiają się cztery całoroczne cykle wykładów: 1. cmentarze i sztuka sepulkralna, 2. kościoły i sztuka sakralna, 3. orbis christianus antiquus (orientalis $i$ occidentalis), 4. ikonografia wczesnochrześcijańska; ukoronowaniem jej badań nad kulturą artystyczną starożytności chrześcijańskiej są dwa pierwsze powojenne polskie podręczniki z zakresu sztuki wczesnochrześcijańskiej $(1983,1985)$. Prof. B. Filarska pełniła swe funkcje na ATK do 30 września 1989 roku, kiedy odeszła na emeryturę.

W roku akademickim 1994/95 obok dwóch istniejących katedr: Katedry Archeologii Chrześcijańskiego Bliskiego Wschodu, Katedry Archeologii Chrześcijańskiego Zachodu powstają dwie nowe katedry: Katedra Archeologii Chrześcijańskiej Słowiańszczyzny oraz Katedra Archeologii Palestyny. Kierownikiem Katedry Archeologii Chrześcijańskiego Zachodu zostaje prof. Witold Dobrowolski, a Katedry Archeologii Chrześcijańskiej Słowiańszczyzny prof. Maria Miśkiewicz. Stanowiska kierowników dwu pozostałych katedr pozostają nie obsadzone. Po odejściu prof. Witolda Dobrowolskiego kuratorem kierunku została prof. Maria Miśkiewicz, a nowym kierownikiem Katedry Archeologii Chrześcijańskiego Zachodu została prof. Elżbieta Jastrzębowska.

\author{
DE CATHEDRA ARCHEOLOGIAE CHRISTIANAE \\ IN ACADEMIA THEOLOGIAE CATHOLICAE VARSOVIAE
}

(Argumentum)

Hac in dissertatiuncula historia atque insignes res gestae Cathedrae Archeologiae Christianae in Academia Theologiae Catholicae Varsoviae eiusque influxus in culturam christianam Polonorum annis 1921-1995 breviter exponuntur. 